\title{
Reactions to problems in marriage
}

Betul BATTALOĞLU INANÇ ( $\nabla$ betulbattaloglu00@gmail.com )

Muğla Sıtkı Koçman University https://orcid.org/0000-0001-7478-5451

\section{Research Article}

Keywords: Domestic violence, marriage, reactions, Turkey

Posted Date: January 11th, 2022

DOI: https://doi.org/10.21203/rs.3.rs-1234977/v2

License: (1) This work is licensed under a Creative Commons Attribution 4.0 International License. Read Full License 


\section{Abstract}

Purpose: Violence within the family is a common problem that can be seen in almost most socio-economic groups, societies, all ages and all educational levels. This study was planned to investigate the behavior and attitudes and marital satisfaction levels of the spouses in the family life process.

Methods: All citizens 18 years and older that are living in households in the Republic of Turkey have been included. Considering the existing population records, a stratified two-stage systematic cluster sampling method was applied. . Comparisons by the sex, educational level, and marital status satisfied were performed with the use of chi-square and multivariate regression analysis, correlation analysis. A p-value $<0.05$ was considered to be statistically significant.

Result: Violent behaviors such as doing harm, breaking and hitting things were more intense in men. Aply physical violence was more common among males. Only maintaining silence, getting angry or sulking was statistically significant in women $(p<0.000)$. Yelling, scolding, humiliating, separating the bedroom and decreasing spending money was statistically significant in males $(p<0.000)$.

Conclusion: All concepts related to marriage should be well defined because spouse satisfaction and conflicts can have different meanings. It suggests that raising awareness about domestic violence against women, knowing solution methods, informing about their rights and increasing social support may be beneficial in solving the problem.

\section{Introduction}

Studies have shown that good spousal support and understanding plays an important role in the functioning of the family relationship. Expectations of happiness, satisfaction and emotions are possible with mutual understanding and good communication in marriage. In earlier years, conflicts and violence within the family were ignored as they had been experienced behind closed doors and even it was considered as a private matter that they have to resolve within themselves considering the privacy of the family until 1993 when the United Nations General Assembly adopted the declaration on the elimination of violence against women ${ }^{1-4}$. In this statement, violence against women includes the definition as "any act, threat, coercion or arbitrary deprivation of liberty based on gender. All such acts, whether in private family life or in public life can result in a statement of physical, sexual / or psychological harm." With this definition, violence could now be voiced and was accepted that it was not a normal behaviour. With this general acceptance, people no longer find domestic violence or family conflicts acceptable due to stress or other reasons. This is true not only in married couple relationships but also in intimate partner relationships. In most studies, the definition of violence covers both physical and sexual violence against women. However, in rare cases, also emotional or psychological violence is included in the definition of spousal violence against to women. This may indicate that emotional neglect and abuse which is partially overlooked, unnoticed, and as seems unremarked could be in fact difficult to describe, detect and even recognized for the victim who was been exposed to this kind of violence type. However while emotional abuse can happen without any other existing form of violence, it is also quite common for emotional abuse to occur in other types of intimate partner relationships. Emotional abuse can be defined as any non-physical behavior or attitude designed to control, subjugate, punish or isolate another person using violence, humiliation or fear ${ }^{3-9}$. In this context, knowing emotional family interactions and reactions is important to detect emotional violence easily. It is also thought that domestic violence occurs as a result of the conflicts and dissatisfaction of the spouses. Because family life has been identified as one of the important factors contributing to the formation of family members' life styles ${ }^{10,8}$. World Health Organization is reported that $71 \%$ of women between the ages of 18 and 60 have experienced emotional, physical or sexual violence in their relationships and $15-29 \%$ of women globally exposed to multiple violence and harassment ${ }^{6}$.

If we are faced with such a picture, it seems important to understand the satisfaction of family life, to know the attitudes of spouses to each other, and the variety of reactions the family can show in their daily lives. This study is discussed to see what the reactions of spouses to each other when they encounter a problem and the satisfaction in their marriage. Because, violence against women has increased significantly in our country. Are this violence types is the result of a life of violence that is now accustomed to in family life? We wanted to see this.

\section{Methods}

This study is a Turkish Family Structure Research study was done by taking into account of the current population records for belong to 2016 year's of the Family and Social Research Directorate. Involved all citizens aged 18 and over living in households in Turkey that were determined according to multi-stage, stratified and random sampling methods in order to obtain the situation regarding family structure and lifestyle. This research is carried out every 5 years and after the data is collected, it is published publicly. Our study is the evaluation of these published open data. The questionnaires applied to the participants were administered face to face and by trained pollsters, each participant entered a questionnaire with his own decision, by applying all steps of ethical protocols, attention was paid to the protection of the information provided by the individuals. Violence in the survey is the definition adopted in the United Nations Declaration on the Elimination of Violence Against Women. "Violence is a gender-sensitive act or threat to behave in a way that causes physical, sexual or psychological pain or suffering in social or private life."

In the questionnaire, the question "How will your spouse react if you have a problem that you cannot solve by talking? (Attitude in the last 1 year)" which is asked to women and men indicates the response of the spouse in case of a problem.

Physical violence includes:

- Slapping or throwing something that could hurt

- Pushing or pulling hair

- Punching or hitting with something that could hurt 
- Kicking, dragging or beating

- Trying to smother or burn

- Using or threatening to use pistols, knives or other weapons

Sexual violence includes:

- Being physically forced to have sexual intercourse under coercion

- Having sexual intercourse horrifyingly or even in case of unwillingness due to fear

- Being forced to do something that is insulting or degrading ${ }^{11}$.

In the analysis regarding the age group; $15-19,20-24,25-29,30-34,35-39,40-44,45-49,50-54,55-59,60-64$ and $65+$ age groups were used. The statistical analysis was performed by SPSS statistical software and Microsoft Office Excel. Defining statistics are made with an average \pm standard deviation value for the constant variables and by giving the frequency and percentage for the numerical variables. Comparisons by the sex, educational level, and marital status satisfied were performed with the use of chi-square and multivariate regression analysis, correlation analysis. A p-value $<0.05$ was considered to be statistically significant. All of the statistical analyses were performed with the use of SPSS software, version 20.

\section{Results}

Men and women stated their answers to the problems they had when they encountered a problem in their marital life in Tables 1 and 2 . Table 3 shows their satisfaction with their marriage. According to women, the first attitude of men in family life when they encounter a problem is to raise their voices and scold women. According to men, the first attitude of women when they encounter a problem in their family life is to raise their voices, stay silent, get angry or sulk. Shouting at each other was the most common behavior of spouses. Violent behaviors such as doing harm, breaking and hitting things were more intense in men. Physical violence was more common among males. Only maintaining silence, getting angry or sulking was statistically significant in women ( $\mathrm{k}<0.000$ ). Yelling, scolding, humiliating, separating the bedroom and decreasing spending money was statistically significant in males ( $p<0.000)$. In addition there was statistical significance in terms of leaving home $(p<0.013)$, breaking / destroying some of their belongings $(p<0.027)$ and physical violence $(p<0.001)$ in men. Some behavioral patterns in men were associated with other behaviors: Leaving home and seperating the beds $(p=0.000)$ was associated with leaving home and humiliation ( $p=0.007)$; Destruction / fragmentation of items and separation of beds ( $=0.002)$, destruction / breakdown of items and deduction of money for expenses $(p=0,000)$ were associated with destruction / breakdown of things and leaving home $(p=0.000)$. Forced / physical violence was also found to be associated with leaving the room at the time of violence $(p=0.005)$.

\section{Discussion}

Emotional abuse includes verbal aggression, independence control, isolation, teasing, humiliation, or any behavior that reduces self-esteem. It aims to disrupt the emotional and psychological health of the person and is often a precursor of physical abuse ${ }^{9}$. During pregnancy, the rate of emotional abuse was reported as $35.3 \%$ in Vietnamese women and $30.7 \%$ in Canadian and Mexican women ${ }^{12}$. Some studies have found that emotional aggression is similar between men and women ${ }^{8}$. According to a study conducted by Coker $^{13}$. in our country, life-long physical violence against the spouse is $13.3 \%$ for females and $5.8 \%$ for males; The frequency of sexual violence is $4.3 \%$ for women and $0.2 \%$ for men; The prevalence of spousal violence was found to be $12.1 \%$ among women and $17.3 \%$ among men. In India, it has been found that $31 \%$ of women aged $15-49$ have experienced physical, sexual or psychological abuse by a close partner in their lifetime and $48 \%$ experienced at least one controlling behavior by their husbands ${ }^{14}$. The most common form of violence observed in our study was emotional violence. When a problem was encountered, yelling and scolding were used very often. Another study in our country found that $44 \%$ of married women were subjected to emotional violence / abuse at any moment in their lives, and the way this act of violence was seen as insult, defamation and slander $(37 \%)^{15}$. In this context, the data of our study are compatible with the literature. Yelling and humiliation were the most common methods men used, women also shouted but then remained silent, not speaking. Even these different types of answers can be interpreted as an effort to prevent emotional violence against women and the physical violence that may follow. Because if the woman continues to shout, then physical violence can be applied immediately. This is why women seem to have learned to be quiet. Because the woman knows that emotional abuse is the footsteps of physical violence that may come. Because the studies say that emotional abuse / violence are the basic starting steps of violence that lays the groundwork for physical and sexual violence ${ }^{6-8}$, 15, 16. Our findings seem to indicate this.

Because the insult was associated with the separation of the bed and leaving the house, that is, the dose and form of violence was increasing in the responses of the spouses. We can think that when violent behavior started, another type of violence was added and observed, which was in accordance with the literature. It was observed in those who were subjected to emotional, physical or sexual violence, subjected to multiple violence and abuse as well. Of course the lack of visibility like physical violence makes emotional violence difficult to recognize and understand. Because, in our study, except for spouses who are very satisfied with their marriage, satisfaction with marriage is around $77 \%$.

Emotional violence, by its nature, differs from harsh and hurtful physical violence as an invisible form of violence that aims to exploit, hurt, and destroy emotions. The person's ego is almost systematically weakened so that it can be controlled.

Therefore, the person may not realize that he / she has lost his / her value in the face of such behavior, his / her ability to evaluate reality may be impaired which our study found that physical violence and emotional violence were both visible, yet the very high marital satisfaction expressed was interpreted as

Page $3 / 5$ 
such. It is considered as emotional traumas of the person who distorts reality.

Descriptions of violence of spouses, their relationships with each other can give information about their acceptance of family life ${ }^{17}$. Because there is no certainty of definitions here, there are differences in acceptance. There is neither a single definition of violence nor a formula to decide what is happening in the relationship. We think that if the behavior that is accepted as bad and bad in a relationship begins to be and becomes more frequent, people should question this.

\section{Limitations}

Although this data content involves all the data of Turkey, involvement of only married people to the research and lack of data continuity are basic limitations. This study should also be explored in adolescent relationships, unmarried adult relationships or lesbian, gay, bisexual or transgender individuals. Because this can be a way of learning how society treats violence.

\section{Conclusions}

Most of the research focuses on physical and sexual abuse in home life. There is also an obvious use of physical violence in this study. However, psychological violence often does not seem to be taken seriously. In intense family relationships, any emotion from love to anger, can turn into a field of violence projection that can be changed. These intense emotions which can even put pressure on our loved ones can sometimes make them feel sad or even bored. Moreover, the severity and differences in the evaluation of these feelings constitute the fine line the degree and extent of the violence. There is no model of how a healthy relationship should be. It is important to consider how well the relationship meets our basic needs. In healthy relationships, partners do not yell, insult or hurt others; These kinds of humiliating and bad situations are unusual. Recognizing and defining violence seems to be the best way to avoid direct violence.

\section{Declarations}

Disclaimer: None.

Conflict of Interest: None.

Source of Funding: None.

\section{References}

1. Verhofstadt L, Devoldre I, Buysse A, Stevens M, Hinnekens C, Ickes W, Davis M. The role of cognitive and affective empathy in spouses' support Interactions: An observational study. PLOS ONE. 2016; 11(2): e0149944.

2. Erberk E, Beştepe E, Akar H, Eradamlar N, Alpkan RL. Evlilik Uyumu. [Marital Adjustment ]. Düşünen Adam. 2005; 18(1): 39-47.

3. Mears DP, Visher CA. Trends in understanding and addressing domestic violence. J Interpers Violence. 2005; 20(2): $204-211$.

4. Declaration on the elimination of violence against women. New York, NY, United Nations, 1993 (United Nations General Assembly resolution, document A/RES/48/104)

5. Amegbor PM, Pascoe L. Variations in emotional, sexual, and physical intimate partner violence among women in Uganda: A multilevel analysis. J Interpers Violence. 2019; https://doi.org/10.1177/0886260519839429

6. World Health Organization. (2005). WHO Multi-country study on women's health and domestic violence against women Geneva, Switzerland: Author. https://www.who.int/reproductivehealth/publications/violence/24159358X/en/

7. Minh Le T, Morley C, Hill PS, Tu Bui Q, Dunne MP. The evolution of domestic violence prevention and control in Vietnam from 2003 to 2018 : a case study of policy development and implementation within the health system. Int J Ment Health Syst. 2019; 13: 41.

8. Yoshihama M, Blazevski J, Bybee D. Gender (A)symmetry in correlates of perpetration of intimate partner violence: gender (a) symmetry in ıpv and the role of gender attitudes. Violence Against Women. 2019; doi.org/10.1177/1077801219848488

9. Karakurt G, Silver KE. Emotional abuse in intimate relationships: The role of gender and age. Violence Victims. 2013; 28(5): 804-821.

10. Bodner N, Kuppens P, B Allen N, B Sheeber L, Ceulemans E. Affective family interactions and their associations with adolescent depression: A dynamic network approach. Dev Psychopathol. 2018; 30(4):1459-1473.

11. Turkish Statistical Institute (TURKSTAT) of the Republic of Turkey. (2016). Address based population registration system and suicide statistics. https://web.turkstat.gov.tr/VeriTabanlari.do?vt_id=1\&ust_id=110

12. Tho Nhi T, Thuy Hanh NT, Duc Hinh N, Van Toan N, Gammeltoft T, Rasch V, Meyrowitz DW. Intimate partner violence among pregnant women and postpartum depression in Vietnam: A longitudinal study. BioMed Res Int. 2019; Article ID 4717485: 9 pages. 
13. Coker AL, Davis KE, Arias I, Desai S, Sanderson M, Brandt HM, Smith PH. Physical and mental health effects of Intimate partner violence for men and women. Am J Prev Med. 2002; 23(4): 260-268.

14. Richardson R, Nandi A, Jaswal S, Harper S. The efect of intimate partner violence on women's mental distress: a prospective cohort study of 3010 rural Indian women. Soc Psychiatry and Psychiatr Epidemiol. 2019; doi.org/10.1007/s00127-019-01735-5

15. T.R. Ministry of Family and Social Policies. Research on domestic violence against women in Turkey 2015. In. Yüksel-Kaptanoğlu, I., Çavlin, A. Prevalence of violence against women. Elma Teknik Basım. Ankara. p. 95-97.

16. Azam Ali P, Dhingra K, McGarry JP. A literature review of intimate partner violence and its classifications. Aggress Violent Behav. 2016; 31 : 16-25.

17. Grych JH, Fincham FD. Marital conflict and children's adjustment: A cognitive-contextual framework. Psychol Bull. 1990; 108(2): 267-290.

\section{Tables}

Table-1 Reactions against to spouses give when confronted with a problem according to men by age group

\begin{tabular}{|c|c|c|c|c|c|c|c|c|c|c|c|}
\hline $\begin{array}{l}\text { According } \\
\text { to men } \\
(\%)\end{array}$ & $\begin{array}{r}\text { She } \\
\text { raises } \\
\text { hervoice }\end{array}$ & $\begin{array}{r}\text { She remains } \\
\text { silent/suffers } \\
\text { in silence }\end{array}$ & $\begin{array}{r}\text { She gets } \\
\text { cross/ be } \\
\text { in the } \\
\text { sulks }\end{array}$ & $\begin{array}{r}\text { She } \\
\text { reprimands } \\
\text { me }\end{array}$ & $\begin{array}{r}\text { She } \\
\text { leaves } \\
\text { theroom }\end{array}$ & $\begin{array}{r}\text { She } \\
\text { insults } \\
\text { me }\end{array}$ & $\begin{array}{r}\text { She } \\
\text { separates } \\
\text { bedrooms }\end{array}$ & $\begin{array}{r}\text { She } \\
\text { cuts my } \\
\text { spending }\end{array}$ & $\begin{array}{r}\text { She } \\
\text { leaves } \\
\text { the } \\
\text { house }\end{array}$ & $\begin{array}{r}\text { She } \\
\text { destroys/smashes } \\
\text { belongings }\end{array}$ & force/] \\
\hline Total (\%) & 53.0 & 52.1 & 42.2 & 26.7 & 20.1 & 7.6 & 5.1 & 4.2 & 3.6 & 3.5 & \\
\hline $15-19$ & - & $\begin{array}{lll}- & \\
- & & \end{array}$ & - & $\begin{array}{ll}- \\
-\end{array}$ & - & - & - & - & - & - & - \\
\hline $20-24$ & 40.7 & 51.0 & 51.7 & 18.9 & 20.1 & 10.3 & 8.2 & 14.9 & 2.9 & 4.8 & \\
\hline $25-29$ & 50.4 & 52.3 & 48.3 & 23.4 & 23.2 & 7.2 & 4.2 & 3.8 & 3.3 & 3.9 & \\
\hline $30-34$ & 55.9 & 58.4 & 51.1 & 28.0 & 26.4 & 7.9 & 4.9 & 5.1 & 3.9 & 4.9 & \\
\hline $35-39$ & 53.6 & 52.0 & 48.3 & 27.9 & 25.0 & 9.0 & 5.5 & 4.5 & 4.2 & 3.6 & \\
\hline $40-44$ & 55.0 & 54.5 & 46.3 & 25.9 & 22.6 & 8.3 & 5.9 & 4.6 & 3.8 & 3.8 & \\
\hline $45-49$ & 56.4 & 54.8 & 43.5 & 27.7 & 22.5 & 7.5 & 6.0 & 3.8 & 4.2 & 4.0 & \\
\hline $50-54$ & 52.2 & 52.9 & 38.9 & 25.6 & 17.3 & 6.6 & 5.6 & 4.0 & 3.4 & 2.7 & \\
\hline $55-59$ & 52.1 & 52.8 & 35.8 & 28.1 & 17.4 & 8.2 & 6.0 & 4.4 & 4.0 & 3.5 & \\
\hline $60-64$ & 52.5 & 47.9 & 31.6 & 25.7 & 13.7 & 5.4 & 4.1 & 2.9 & 2.9 & 2.6 & \\
\hline $65+$ & 48.4 & 42.8 & 32.6 & 27.3 & 11.0 & 6.8 & 2.9 & 2.9 & 2.7 & 2.1 & \\
\hline
\end{tabular}

Table-2 Reactions against to spouses give when confronted with a problem according to women by age group

\begin{tabular}{|c|c|c|c|c|c|c|c|c|c|c|c|}
\hline $\begin{array}{l}\text { According } \\
\text { to women } \\
(\%)\end{array}$ & $\begin{array}{r}\mathrm{He} \\
\text { raises } \\
\text { hisvoice }\end{array}$ & $\begin{array}{r}\mathrm{He} \\
\text { reprimands } \\
\text { me }\end{array}$ & $\begin{array}{r}\text { He remains } \\
\text { silent/suffers } \\
\text { in silence }\end{array}$ & $\begin{array}{r}\text { He } \\
\text { gets } \\
\text { cross/ } \\
\text { be in } \\
\text { the } \\
\text { sulks }\end{array}$ & $\begin{array}{r}\text { He } \\
\text { leaves } \\
\text { the } \\
\text { room }\end{array}$ & $\begin{array}{r}\text { He } \\
\text { insults } \\
\text { me }\end{array}$ & $\begin{array}{r}\text { He } \\
\text { leaves } \\
\text { the } \\
\text { house }\end{array}$ & $\begin{array}{r}\mathrm{He} \\
\text { destroys/smashes } \\
\text { belongings }\end{array}$ & $\begin{array}{r}\text { He cuts } \\
\text { my } \\
\text { spending }\end{array}$ & $\begin{array}{r}\text { He } \\
\text { separates } \\
\text { bed } \\
\text { rooms }\end{array}$ & $\begin{array}{r}\text { He us } \\
\text { force/physi } \\
\text { violer }\end{array}$ \\
\hline Total (\%) & 68.5 & 46.2 & 43.4 & 35.8 & 21.0 & 14.2 & 6.7 & 6.6 & 6.1 & 6.1 & ! \\
\hline $15-19$ & 65.5 & 45.2 & 62.6 & 40.0 & 24.0 & 15.6 & 11.5 & 8.8 & 8.7 & 6.3 & \\
\hline $20-24$ & 66.8 & 40.2 & 40.2 & 38.0 & 23.4 & 10.1 & 5.9 & 6.5 & 6.3 & 7.1 & \\
\hline $25-29$ & 65.7 & 41.8 & 49.0 & 38.7 & 24.8 & 13.4 & 7.0 & 6.9 & 6.6 & 5.1 & \\
\hline $30-34$ & 70.1 & 46.2 & 47.0 & 38.0 & 25.3 & 13.8 & 7.7 & 7.1 & 7.2 & 5.9 & 2 \\
\hline $35-39$ & 70.8 & 47.4 & 44.9 & 39.0 & 25.9 & 15.9 & 7.8 & 9.2 & 7.4 & 8.1 & 1 \\
\hline $40-44$ & 70.3 & 47.9 & 46.4 & 37.2 & 21.8 & 16.2 & 7.5 & 7.0 & 6.6 & 7.7 & 1 \\
\hline $45-49$ & 69.5 & 47.0 & 40.3 & 36.8 & 20.1 & 13.5 & 6.5 & 6.4 & 6.2 & 5.6 & F \\
\hline $50-54$ & 69.5 & 48.4 & 41.8 & 32.2 & 17.8 & 14.7 & 6.0 & 7.1 & 5.3 & 5.5 & F \\
\hline $55-59$ & 72.8 & 50.7 & 42.7 & 33.1 & 17.0 & 14.3 & 6.5 & 5.5 & 5.1 & 5.8 & ! \\
\hline $60-64$ & 64.3 & 44.7 & 41.3 & 30.8 & 15.5 & 12.0 & 5.5 & 3.9 & 3.9 & 5.1 & \\
\hline $65+$ & 61.6 & 44.5 & 32.8 & 29.7 & 11.6 & 14.1 & 4.6 & 3.6 & 3.6 & 4.1 & \\
\hline
\end{tabular}

Table-3 Satisfaction from marriage bysex. 2016

\begin{tabular}{lccc}
\hline & Male(\%) & Female(\%) & Total(\%) \\
\hline Very satisfied & 16.5 & 15.3 & 15.9 \\
Satisfied & 79.4 & 76.2 & 77.7 \\
Neither satisfied. nor satisfied & 2.7 & 6.1 & 4.5 \\
Not satisfied & 1.1 & 1.6 & 1.4 \\
Not satisfied at all & 0.2 & 0.8 & 0.5 \\
\hline
\end{tabular}

